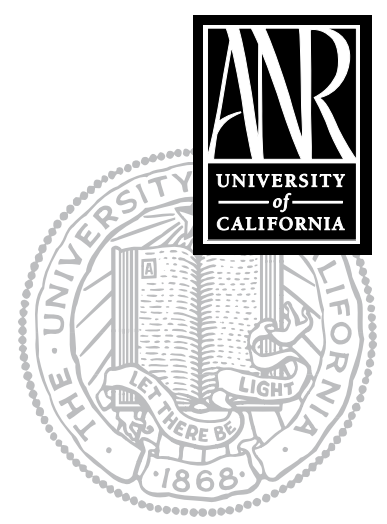

UNIVERSITY OF CALIFORNIA

Division of Agriculture and Natural Resources http://anrcatalog.ucdavis.edu

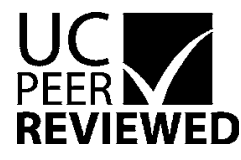

\title{
Causes and Management of Runoff from Surface Irrigation in Orchards
}

LAWRENCE J. SCHWANKL, UC Cooperative Extension Irrigation Specialist; BLAINE R. HANSON, UC Cooperative Extension Irrigation and Drainage Specialist; and TERRY L. PRICHARD, UC Cooperative Extension Water Management Specialist

\section{INTRODUCTION}

The California State Water Code requires anyone discharging waste that could affect the waters of the state to obtain a permit or coverage under a waiver. Agricultural runoff, whether from irrigation or rainfall, that leaves a property has been determined to likely contain waste (sediment, nutrients, chemicals, etc.).

Compliance under the Irrigated Lands Conditional Waiver is available to agricultural landowners with irrigated lands who have runoff from their property resulting from irrigation practices or winter rainfall. If no runoff from any source leaves a property, the California Water Code does not impact the property owner.

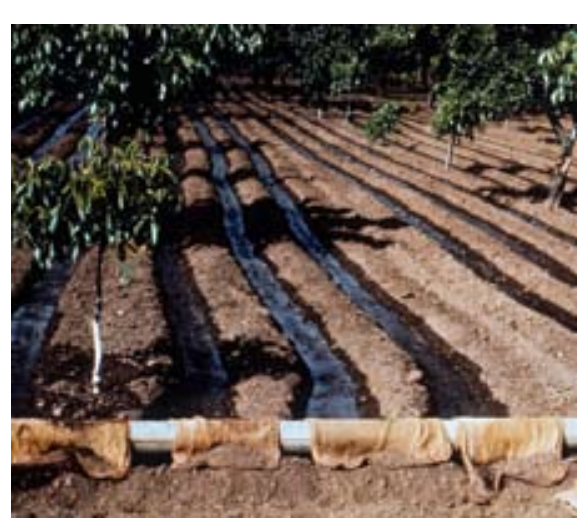

Figure 1. Furrow irrigation in an orchard. Photo: Lawrence J. Schwankl.

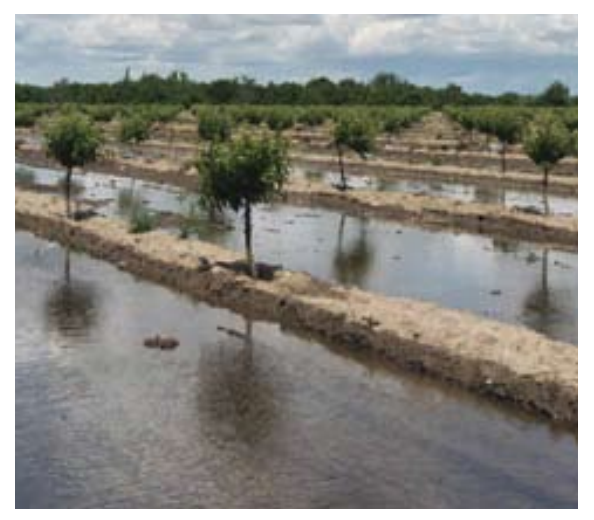

Figure 2. Border (flood) irrigation in an orchard. Photo: Lawrence J. Schwankl.

\section{RUNOFF IN SURFACE IRRIGATION}

Many orchards in California use surface irrigation systems such as furrow irrigation (fig. 1) or border (or flood) irrigation (fig. 2). The flat topography of California's Central Valley lends itself to accurate leveling, and many areas have traditionally had inexpensive surface water supplies available.

Under surface irrigation, water is introduced into furrows or border checks at the top of the orchard. As the water flows downslope, some of the water infiltrates the soil. Water is applied in excess of that which infiltrates, and the excess water flows, or advances, across the orchard.

When water reaches the lowest part, or end, of the orchard, "tailwater" runoff begins unless the water is shut off or the end of the orchard is blocked with berms to keep the water in the orchard. Allowing runoff is a common part of normal surface irrigation to ensure that sufficient water is applied at the lowest end of the orchard.

In border irrigation, the water should be shut off before it reaches the end of the orchard. However, if the water is shut off too soon, the end of the orchard may be underirrigated. Shutting the water off before it reaches the end of the orchard is more common when border irrigation is used than when furrow irrigation is used. In furrow irrigation, good distribution of infiltrated water in the orchard is often accompanied by 10 to 15 percent of the applied water being lost as runoff.

Overirrigation, in which more water is applied than can be stored in the trees' root zone, can lead to greater tailwater runoff problems. For further information on determining the proper irrigation amount to apply, see Understanding Your Orchard's Water Requirements (ANR Publication 8212); for more information on measuring the amount of irrigation water applied, see Measuring Irrigation Flows in a Pipeline (ANR Publication 8213) and Measuring Applied Water In Surface Irrigation (ANR Publication 8226). 


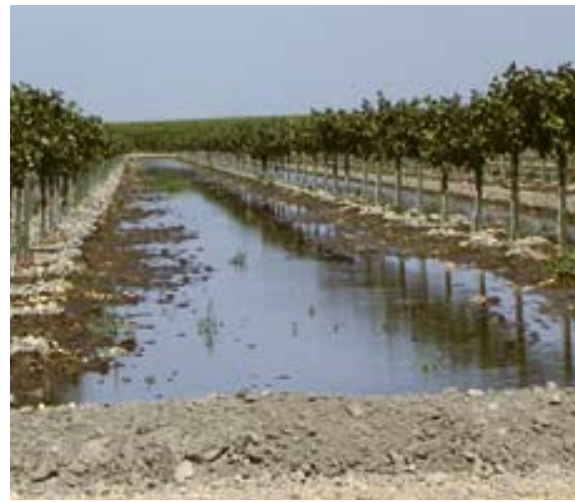

Figure 3. Border-irrigated orchard in which the irrigation water is kept in the orchard through use of soil berms. Photo: Lawrence J. Schwankl.

\section{MANAGING SURFACE RUNOFF}

The following three methods of managing surface runoff from irrigation can be used to minimize the amount of water leaving a property.

\section{Minimize the Amount of Surface Runoff}

Furrow and border irrigation systems should be closely managed to minimize surface runoff. This requires turning the water off either before or as the advancing water reaches the end of the orchard. With border irrigation, this often means that the water must be stopped before it advances to the end of the orchard, since water will continue to advance even after it is turned off. Water will not advance far after a furrow irrigation system is shut off; trees at the end of the row may be underirrigated if this technique is used with furrow irrigation.

\section{Retain All Runoff on the Orchard}

Runoff water can be kept on the orchard by blocking the end and sides of the orchard with a soil berm (fig. 3). The water can either be ponded in the furrows or borders being irrigated or it can be diverted into adjacent dry furrows or borders. Either practice can result in the end of the orchard being overirrigated, which reduces the efficiency of the irrigation and can lead to root disease.

Retaining all stormwater on an orchard is difficult since the amount of runoff water can be extremely large. For more information, see Storing Runoff from Winter Rains (ANR Publication 8211). In order to prevent runoff, the soil intake rate must be extremely high and the soil must be able to rapidly absorb large rainfall events. If water does run off, it may transport wastes, and the property owner will be forced to comply with the State Water Code.

\section{Install Tailwater Return Systems}

Tailwater return systems, in which tailwater runoff is collected in a pond and reused, are common in surface-irrigated row and field crops. They are not as common in orchards, but there is no reason they should not be. A tailwater return system collects the runoff water in a storage pond until it can be reused for irrigation on another section of the orchard or on other land being irrigated. Reusing the collected water maintains high irrigation efficiency and makes room in the pond for additional runoff.

There are installation costs associated with the tailwater return system, energy costs for pumping, and the need to dedicate a piece of land for the pond. For more information on tailwater return systems, see Tailwater Return Systems (ANR Publication 8225).

\section{SUMMARY}

Minimizing the irrigation runoff from surface irrigation is a balance between adequately irrigating trees at the lowest end of the orchard and minimizing tailwater runoff. If the irrigation system minimizes tailwater runoff, the trees at the end of the orchard may be underirrigated. Blocking the ends of the orchard to retain the water eliminates runoff, but it may encourage overirrigation and disease. Tailwater return systems are advantageous since they collect the tailwater runoff for reuse while allowing the trees at the end of the orchard to be adequately, but not overly, irrigated. 


\section{FOR FURTHER INFORMATION}

Storing Runoff from Winter Rains (ANR Publication 8211), 2007.

Understanding Your Orchard's Water Requirements (ANR Publication 8212), 2007.

Measuring Irrigation Flows in a Pipeline (ANR Publication 8213), 2007.

Managing Existing Sprinkler Irrigation Systems (ANR Publication 8215), 2007.

Soil Intake Rates and Application Rates in Sprinkler-Irrigated Orchards (ANR Publication 8216), 2007

Tailwater Return Systems (ANR Publication 8225), 2007.

Measuring Applied Water in Surface Irrigation (ANR Publication 8226) [in process].

To order or obtain printed ANR publications and other products, visit the ANR Communication Services online catalog at http://anrcatalog.ucdavis.edu. You can also place orders by mail, phone, or FAX, or request a printed catalog of our products from:

University of California

Agriculture and Natural Resources

Communication Services

6701 San Pablo Avenue, 2nd Floor

Oakland, California 94608-1239

Telephone: (800) 994-8849 or (510) 642-2431

FAX: (510) 643-5470

E-mail inquiries: danrcs@ucdavis.edu

An electronic version of this publication is available on the ANR Communication Services Web site at http://anrcatalog.ucdavis.edu.

Publication 8214

ISBN-13: 978-1-60107-433-1

ISBN-10: 1-60107-433-6

(C) 2007 by the Regents of the University of California, Division of Agriculture and Natural Resources. All rights reserved.

The University of California prohibits discrimination or harassment of any person on the basis of race, color, national origin, religion, sex, gender identity, pregnancy (including childbirth, and medical conditions related to pregnancy or childbirth), physical or mental disability, medical condition (cancer-related or genetic characteristics), ancestry, marital status, age, sexual orientation, citizenship, or status as a covered veteran (covered veterans are special disabled veterans, recently separated veterans, Vietnam era veterans, or any other veterans who served on active duty during a war or in a campaign or expedition for which a campaign badge has been authorized) in any of its programs or activities. University policy is intended to be consistent with the provisions of applicable State and Federal laws.

Inquiries regarding the University's nondiscrimination policies may be directed to the Affirmative Action/Staff Personnel Services Director, University of California, Agriculture and Natural Resources, 1111 Franklin Street, 6th Floor, Oakland, CA 94607-5201 (510) 987-0096. For a free catalog of other publications, call (800) 994-8849. For help downloading this publication, call (530) 754-5112.

This publication has been anonymously peer reviewed for technical accuracy by University of California scientists and other qualified professionals. This review process was managed by the ANR Associate Editor for Land, Air, and Water Sciences.

pr-1/07-SB/RW 